\title{
Plasma leptin concentrations: gender differences and associations with metabolic risk factors for cardiovascular disease
}

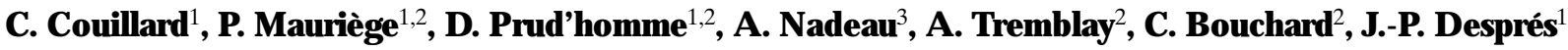 \\ ${ }^{1}$ Lipid Research Center, Laval University Medical Research Center, Sainte-Foy, Québec, Canada \\ ${ }^{2}$ Physical Activity Sciences Laboratory, Laval University, Sainte-Foy, Québec, Canada \\ ${ }^{3}$ Diabetes Research Unit, Laval University Medical Research Center, Sainte-Foy, Québec, Canada
}

Summary The cloning of the obese gene and the characterization of its protein product, leptin, has permitted the study of a new hormone potentially involved in the regulation of adipose tissue mass. The present study examined the gender differences in fasting plasma leptin concentration and its relationship to body fatness, adipose tissue distribution and the metabolic profile in samples of 91 men (mean age \pm SD: $\quad 37.3 \pm 4.8$ years) and 48 women (38.5 \pm 6.8 years). Plasma leptin concentrations were strongly associated with body fat mass measured by underwater weighing [men: $r=0.80, p<0.0001$; women: $r=0.85, p<0.0001]$. In both genders, plasma leptin levels were also strongly correlated with waist girth as well as cross-sectional areas of abdominal subcutaneous and visceral adipose tissue measured by computed tomography. Women had, on average, plasma leptin concentrations that were three times higher than men. Furthermore, this gender difference remained significant when comparing men and women matched for similar levels of body fat mass. The associations between plasma leptin and lipoprotein concentrations were dependent of adiposity. In both men and women, elevated fasting plasma leptin levels were associated with higher plasma insulin concentrations, but only in women was the association maintained after correction for fat mass. Thus, results of the present study show that women have higher plasma leptin levels compared to men, independent of the concomitant variation in total body fat mass. Furthermore, our results also suggest that, in women, the association between plasma leptin and insulin concentrations is independent of adiposity, a finding which provides further support to the observation that adipose tissue leptin secretion may be upregulated by insulin. [Diabetologia (1997) 40: 1178-1184]

Keywords Leptin, gender differences, insulin, lipoproteins.
Obesity results from an imbalance between energy intake and expenditure. Furthermore, obesity has long been recognized to have detrimental effects on health including an increased risk of cardiovascular disease (CVD) [1]. In this regard, the recent cloning

Received: 18 February 1997 and in revised form: 28 April 1997

Corresponding author: J.-P. Després, Ph.D., Lipid Research Center, Laval University Medical Research Center, 2705 Bd. Laurier, Room TR-93, Sainte-Foy (Québec), Canada G1V 4G2 A bbreviations: CVD, Cardiovascular disease; AT, adipose tissue; FM, fat mass; CT, computed tomography; OGTT, oral glucose tolerance test; CHOL, plasma cholesterol; apo, apolipoprotein. of the mouse (ob) and human (OB ) obese genes and the characterization of its protein product, leptin [2], has been a breakthrough of potentially great importance for the understanding of the pathophysiology of obesity.

Leptin has been shown to lower body weight by reducing food intake and increasing energy expenditure in leptin-deficient obese mice (ob/ob) and also to normalize blood glucose levels in the same animals [2-8]. Leptin is secreted by white adipose cells and is exclusively expressed in adipose tissue (AT) [2, 913]. In this regard, numerous studies have reported a strong relationship between adiposity and plasma leptin concentrations or its AT mRNA levels [1421]. Furthermore, expression of the obese gene is 
believed to be regulated by insulin both in vivo and in vitro [3, 13, 22, 23].

Thus, the objectives of the present study were: 1) to examine the potential relationships of body fat mass (FM) assessed by underwater weighing, plasma lipid levels, insulin as well as glucose concentrations, with plasma leptin levels in both men and women, and 2) to test the potential gender difference in plasma leptin levels when adjusting for the well-known gender difference in total adiposity. For this purpose, morphological and metabolic variables were measured in 91 men (mean age \pm SD: $37.3 \pm 4.8$ years) and 48 women $(38.5 \pm 6.8$ years), and associations with fasting plasma leptin examined.

\section{Subjects and methods}

Subjects. Ninety-one men (mean age \pm SD: $37.3 \pm 4.8$ years) and 48 women $(38.5 \pm 6.8$ years) were recruited through the media to participate in this study, which was approved by the medical ethics committee of Laval University and an informed consent document was signed by all participants. A complete physical examination, which also included medical history, was performed by a physician. All participants were nonsmokers and free from diseases requiring treatment. Exclusion criteria included diabetes, monogenic dyslipidaemias or evidence of coronary heart disease.

A nthropometric measurements. Weight, height, waist and hip circumferences were measured following the procedures recommended at the Airlie Conference [24], and the waist-tohip ratio was calculated. Body density was measured by the hydrostatic weighing technique [25], and the mean of six measurements was used in the calculation of body density. Percentage body fat was obtained from body density using the equation of Siri [26].

Computed tomography. Computed tomography (CT) was performed on a Siemens Somatom DRH scanner (Erlangen, Germany) using previously described procedures [27, 28]. Briefly, the subjects were examined in the supine position with both arms stretched above the head. A single CT scan was performed at the abdominal level (between L4 and L5 vertebrae) with a scout abdominal radiograph used as a reference to establish the position of the scan to the nearest millimeter. Total AT area was calculated by delineating the area with a graph pen and then computing the AT surface with an attenuation range of -190 to -30 Hounsfield Units [27-29]. The abdominal visceral AT area was measured by drawing a line within the muscle wall surrounding the abdominal cavity. The abdominal subcutaneous AT area was calculated by subtracting the visceral AT area from the total abdominal AT area.

O ral glucose tolerance test. A 75-g OGTT was performed in the morning after an overnight fast. Blood samples were collected under EDTA and Trasylol (Miles, Rexdale, Ontario, CANADA) through a venous catheter from an antecubital vein at $15,0,15,30,45,60,90,120,150$, and $180 \mathrm{~min}$ for the determination of plasma glucose and insulin concentrations. Plasma glucose was measured enzymatically [30], whereas plasma insulin was measured by RIA with polyethylene glycol separation [31]. However, the assay used for the measurement of plasma insulin showed some cross-reactivity with proinsulin. As diabetes was an exclusion criteria in our study, we believe that such cross-reactivity did not have a significant impact on results obtained and their interpretation.

Plasma lipoprotein analyses. Blood samples were obtained in the morning after a 12 -h fast from an antecubital vein into vacutainer tubes containing EDTA. Plasma cholesterol (CHOL) and triglyceride (TG) levels in plasma and in lipoprotein fractions were measured enzymatically on an RA-1000 Autoanalyzer (Technicon, Tarrytown, N.Y., USA), as previously described [32]. VLDL $(\mathrm{d}<1.006 \mathrm{~g} / \mathrm{ml})$ were isolated by ultracentrifugation, and the HDL fraction was obtained after precipitation of LDL in the infranatant $(\mathrm{d}>1.006 \mathrm{~g} / \mathrm{ml})$ with heparin and $\mathrm{MnCl}_{2}$ [33]. The cholesterol content of $\mathrm{HDL}_{2}$ and $\mathrm{HDL}_{3}$ subfractions was also determined after further precipitation of $\mathrm{HDL}_{2}$ with dextran sulphate [34]. Total apolipoprotein (apo) $\mathrm{B}$ concentration was measured in plasma by the rocket immunoelectrophoretic method of Laurell, as previously described [35]. The lyophilized serum standard for apo B measurement was prepared in our laboratory and calibrated with reference standards obtained from the Centers for Disease Control (Atlanta, GA., USA).

Plasma leptin concentrations. Fasting plasma leptin concentrations were determined with a highly sensitive commercial double-antibody RIA (Human Leptin Specific RIA Kit, LINCO Research, St.-Louis, MO., USA) which detects relatively low leptin levels of $0.5 \mathrm{ng} / \mathrm{ml}$ and which does not crossreact with human insulin, proinsulin, glucagon, pancreatic polypeptide or somatostatin. Our coefficients of variation for the repeated assays ranged from 4.0 to $5.5 \%$ for lower leptin concentrations and from 6.5 to $8.5 \%$ for higher plasma leptin concentrations.

Statistical analysis. Student's t-tests were used to examine gender differences. The same procedure was also used for the comparison of subgroups matched on the basis of body FM. In these analyses, we individually paired men $(n=26)$ and women $(n=26)$ for total body FM (within a maximal difference of $2 \mathrm{~kg}$ ) and compared their respective fasting plasma leptin and insulin concentrations as well as their abdominal subcutaneous and visceral AT accumulation. Pearson product-moment correlation coefficients were used to examine associations among variables. All analyses were performed with the SAS statistical package (SAS Institute, Cary, N. C., USA).

\section{Results}

Physical and metabolic characteristics of subjects are shown in Table 1 . Indices of body fatness showed significant gender differences as percentage body fat and body FM (in $\mathrm{kg}$ ) were higher in women compared to men. Women also showed higher levels of subcutaneous AT measured by CT compared to men. However, despite the fact that women displayed higher levels of total body fat than men, no significant gender difference was found in visceral AT accumulation. With the exception of lower plasma HDL-, $\mathrm{HDL}_{2}$ - and $\mathrm{HDL}_{3}$-cholesterol concentrations and an increased $\mathrm{CHOL} / \mathrm{HDL}$-cholesterol ratio in men, no significant gender difference was noted in the remaining variables of the plasma lipid profile. Furthermore, men were characterized by higher insulin and glucose concentrations in the fasting state compared 
Table 1. Physical and metabolic characteristics of subjects

\begin{tabular}{|c|c|c|}
\hline Variables & $\begin{array}{l}\text { Men } \\
(n=91)\end{array}$ & $\begin{array}{l}\text { Women } \\
(n=48)\end{array}$ \\
\hline Age (years) & $37.3 \pm 4.8$ & $38.5 \pm 6.8$ \\
\hline Weight $(\mathrm{kg})$ & $82.7 \pm 12.9$ & $75.4 \pm 18.9^{b}$ \\
\hline Body-mass index $\left(\mathrm{kg} / \mathrm{m}^{2}\right)$ & $27.3 \pm 4.0$ & $29.0 \pm 7.1$ \\
\hline$\%$ Body fat & $25.8 \pm 6.8$ & $37.6 \pm 12.1^{\mathrm{f}}$ \\
\hline Fat mass $(\mathrm{kg})$ & $22.1 \pm 8.4$ & $30.3 \pm 15.6^{\mathrm{d}}$ \\
\hline Fat free mass $(\mathrm{kg})$ & $60.9 \pm 6.2$ & $45.2 \pm 5.6^{\mathrm{f}}$ \\
\hline Waist girth (cm) & $96.1 \pm 12.0$ & $87.1 \pm 15.6^{\mathrm{e}}$ \\
\hline Waist: hip ratio & $0.94 \pm 0.06$ & $0.81 \pm 0.05^{\mathrm{f}}$ \\
\hline \multicolumn{3}{|c|}{ CT derived abdominal A T areas $\left(\mathrm{cm}^{2}\right)$} \\
\hline Subcutaneous & $251 \pm 106$ & $379 \pm 213^{\mathrm{f}}$ \\
\hline Visceral & $126 \pm 52$ & $108 \pm 61$ \\
\hline \multicolumn{3}{|l|}{ M etabolic profile } \\
\hline Cholesterol (mmol/l) & $5.02 \pm 0.78$ & $5.08 \pm 0.92$ \\
\hline Triglycerides (mmol/1) & $1.67 \pm 0.91$ & $1.40 \pm 0.68$ \\
\hline HDL-chol $(\mathrm{mmol} / \mathrm{l})$ & $1.02 \pm 0.22$ & $1.18 \pm 0.32^{\mathrm{d}}$ \\
\hline $\mathrm{HDL}_{2}-\operatorname{chol}(\mathrm{mmol} / \mathrm{l})$ & $0.35 \pm 0.15$ & $0.44 \pm 0.21^{\mathrm{c}}$ \\
\hline $\mathrm{HDL}_{3}-\operatorname{chol}(\mathrm{mmol} / \mathrm{l})$ & $0.68 \pm 0.12$ & $0.74 \pm 0.17^{\mathrm{b}}$ \\
\hline Apo B (mg/dl) & $94.4 \pm 21.8$ & $95.3 \pm 23.2$ \\
\hline CHOL/HDL-chol & $5.17 \pm 1.31$ & $4.60 \pm 1.43^{\mathrm{a}}$ \\
\hline Leptin (ng/ml) & $6.2 \pm 3.5$ & $19.9 \pm 15.0^{\mathrm{f}}$ \\
\hline Insulin (pmol/1) & $77.9 \pm 30.9$ & $64.9 \pm 43.9^{\mathrm{a}}$ \\
\hline Glucose $(\mathrm{mmol} / \mathrm{l})$ & $5.16 \pm 0.51$ & $4.92 \pm 0.42^{\mathrm{c}}$ \\
\hline Insulin area $\left(10^{-3} \mathrm{pmol} \cdot 1^{-1} \cdot \min ^{-1}\right)$ & $75.8 \pm 36.9$ & $74.6 \pm 37.7$ \\
\hline Glucose area $\left(10^{-3} \mathrm{mmol} \cdot 1^{-1} \cdot \min ^{-1}\right)$ & $1.18 \pm 0.23$ & $1.12 \pm 0.21$ \\
\hline
\end{tabular}

Values are expressed as means \pm SD.

Gender differences: ${ }^{\mathrm{a}} \mathrm{p}<0.05,{ }^{\mathrm{b}} \mathrm{p}<0.01,{ }^{\mathrm{c}} \mathrm{p}<0.005,{ }^{\mathrm{d}} \mathrm{p}<$ $0.001,{ }^{\mathrm{e}} \mathrm{p}<0.0005,{ }^{\mathrm{f}} \mathrm{p}<0.0001$

to women. However, plasma leptin concentrations were more than three times higher in women than in men.

In both men and women, plasma leptin levels showed strong correlations with adiposity. Figures 1 and 2 illustrate the relationships of plasma leptin concentrations to body FM and waist circumference (Fig.1) as well as to abdominal subcutaneous and visceral AT accumulation (Fig.2). For a given body FM (or any adiposity variables studied), women showed higher plasma leptin concentrations compared to men. We also observed substantial individual variation in plasma leptin levels among subjects with increased adiposity, whether it was evaluated by total body FM, waist girth, subcutaneous or visceral AT accumulation.

Although we observed significant associations between plasma leptin concentrations and lipid levels, statistical adjustment for body FM eliminated those relationships in both genders (Table 2). The associations of plasma leptin concentrations with plasma insulin and glucose levels, either in the fasting state or following the oral glucose load are depicted in Table 3. As opposed to men, correction of the relationships with FM did not eliminate the significance of the association between plasma leptin and insulin concentrations in women.

To better examine the potential gender difference in plasma leptin concentrations, we have also
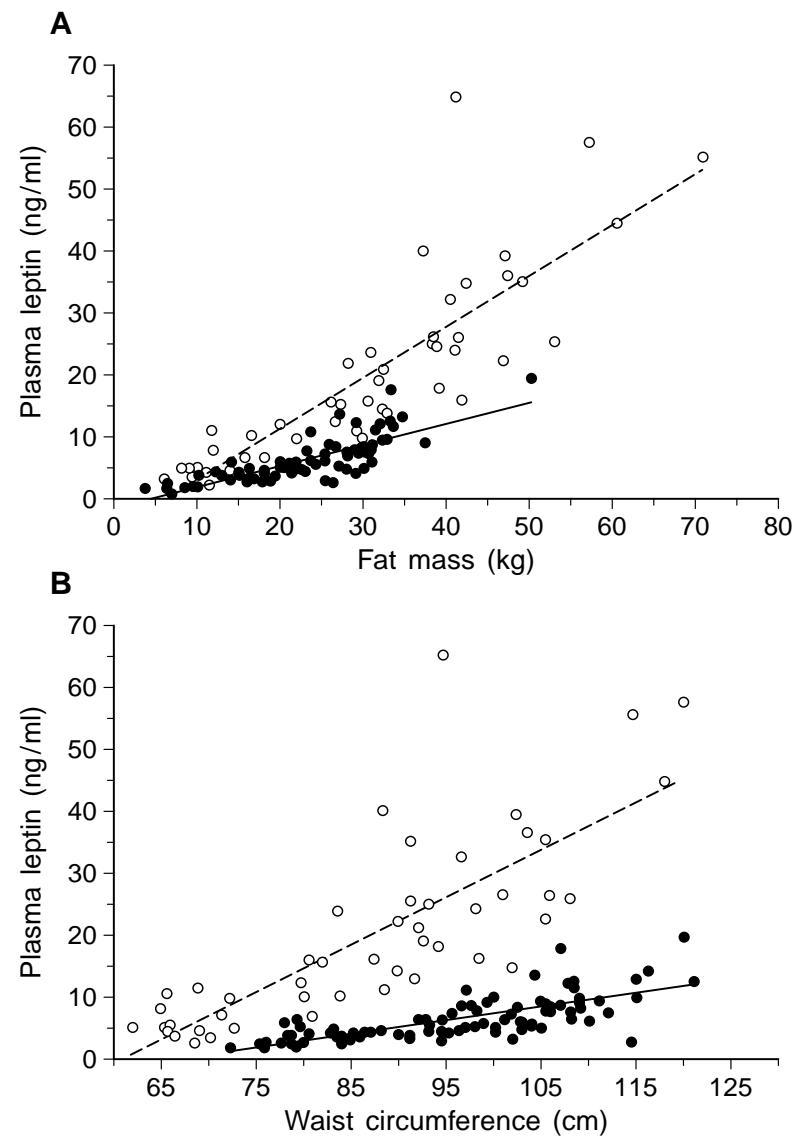

Fig. 1(A, B ). Associations between fasting plasma leptin concentrations and total body FM (A) and waist girth (B) in 91 men $(\bullet)$ and 48 women $(\bigcirc)$. A. Men, $r=0.80, p<0.0001$; women, $r=0.85, p<0.0001$. B. Men, $r=0.73, p<0.0001$; women, $r=0.79, p<0.0001$

compared men $(n=26)$ and women $(n=26)$ who were matched for their total body FM within a 2-kg difference. Figure 3 indicates that although subjects were closely matched for total body FM (mean SEM; men: $20.2 \pm 1.8 \mathrm{~kg}$ vs women: $19.9 \pm 1.8 \mathrm{~kg}$ ), women showed plasma leptin levels which were approximately twice those found in men. Moreover, men displayed significantly higher fasting insulin levels and visceral AT accumulation compared to women. However, no gender difference was found in subcutaneous AT accumulation.

\section{Discussion}

The relationship of abdominal obesity to numerous metabolic disturbances identified as risk factors for the development of CVD, such as dyslipidaemias and NIDDM is well documented [1]. Moreover, although women have on average higher levels of body fat than men, their metabolic profile seems to be less affected by obesity. This is concordant with the results of the present study as women 

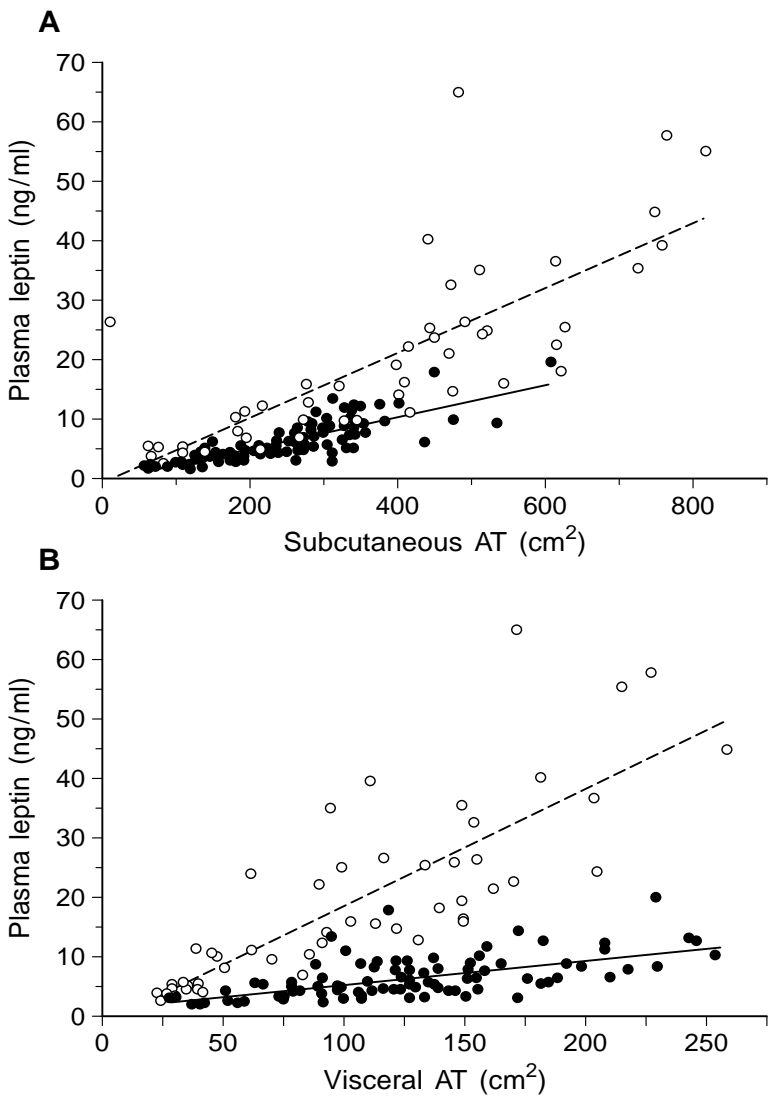

Fig. 2(A, B ). Associations between fasting plasma leptin concentrations and abdominal subcutaneous $(\mathbf{A})$ as well as visceral AT (B) in 91 men $(\bullet)$ and 48 women $(\bigcirc)$. A. Men, $r=0.80, p<0.0001$; women, $r=0.77, p<0.0001$. B. Men, $r=0.59, p<0.0001$; women, $r=0.79, p<0.0001$
A

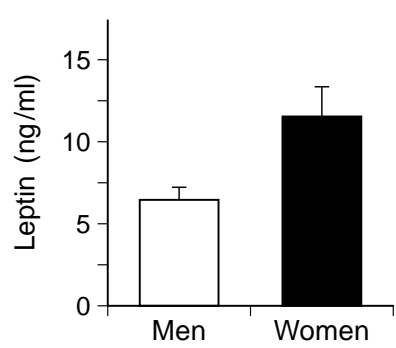

C

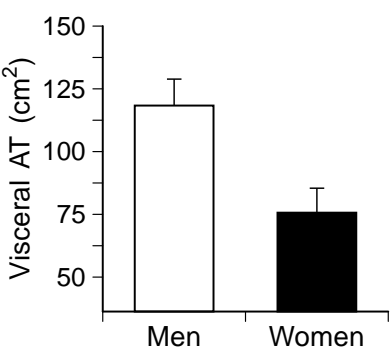

B

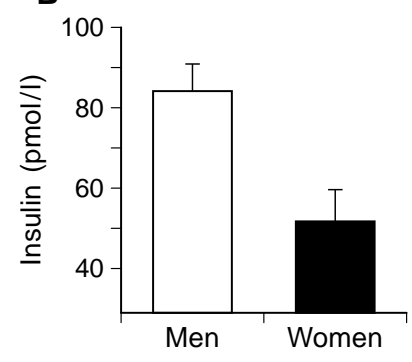

D

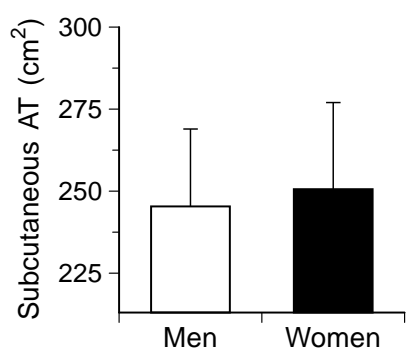

Fig. 3(A - D ). Fasting plasma leptin $(\mathbf{A}, p<0.01)$ and insulin $(\mathbf{B}, p<0.005)$ concentrations, as well as visceral $(\mathbf{C}, p<0.01)$ and subcutaneous (D, NS) AT accumulation in men (white bars; $\mathrm{n}=26$ ) and women (black bars; $\mathrm{n}=26$ ) matched on the basis of total body FM (mean \pm SEM; men: $20.2 \pm 1.8$ vs women: $19.9 \pm 1.8 \mathrm{~kg})$. Values are means \pm SEM
Table 2. Associations between lipid profile variables and fasting plasma leptin concentrations in the 91 men and 48 women of the study

\begin{tabular}{|c|c|c|c|c|}
\hline \multirow[t]{3}{*}{ Variables } & \multicolumn{4}{|c|}{ Plasma leptin (ng/ml) } \\
\hline & \multicolumn{2}{|c|}{ Not adjusted } & \multicolumn{2}{|c|}{$\begin{array}{l}\text { Adjusted } \\
\text { for fat mass }\end{array}$} \\
\hline & Men & Women & Men & Women \\
\hline Cholesterol (mmol/l) & 0.15 & $0.48^{\mathrm{c}}$ & 0.04 & 0.15 \\
\hline Triglycerides (mmol/l) & 0.15 & $0.41^{\mathrm{c}}$ & -0.08 & -0.07 \\
\hline HDL-chol $(\mathrm{mmol} / \mathrm{l})$ & -0.16 & $-0.36^{\mathrm{a}}$ & 0.15 & 0.08 \\
\hline $\mathrm{HDL}_{2}-\operatorname{chol}(\mathrm{mmol} / \mathrm{l})$ & $-0.21^{\mathrm{a}}$ & $-0.40^{\mathrm{b}}$ & 0.09 & 0.02 \\
\hline $\mathrm{HDL}_{3}-\operatorname{chol}(\mathrm{mmol} / \mathrm{l})$ & -0.04 & -0.18 & 0.16 & 0.12 \\
\hline Apo B (mg/dl) & $0.24^{\mathrm{a}}$ & $0.59^{\mathrm{c}}$ & 0.03 & 0.07 \\
\hline Cholesterol/HDL-chol & 0.19 & $0.56^{\mathrm{c}}$ & -0.09 & 0.00 \\
\hline
\end{tabular}

${ }^{\mathrm{a}} \mathrm{p}<0.05,{ }^{\mathrm{b}} \mathrm{p}<0.01,{ }^{\mathrm{c}} \mathrm{p}<0.0005$

Table 3. Correlation coefficients for the associations between plasma glucose and insulin levels measured in the fasting state and following a 75-g oral glucose load (OGTT) and plasma leptin levels in the 91 men and 48 women

\begin{tabular}{|c|c|c|c|c|}
\hline \multirow[t]{3}{*}{ Variables } & \multicolumn{4}{|c|}{ Plasma leptin } \\
\hline & \multicolumn{2}{|c|}{ Not adjusted } & \multicolumn{2}{|c|}{$\begin{array}{l}\text { Adjusted } \\
\text { for fat mass }\end{array}$} \\
\hline & Men & Women & Men & Women \\
\hline $\begin{array}{l}\text { Fasting } \\
\text { Glucose } \\
\text { Insulin }\end{array}$ & $\begin{array}{l}0.44^{\mathrm{b}} \\
0.47^{\mathrm{b}}\end{array}$ & $\begin{array}{l}0.61^{\mathrm{c}} \\
0.66^{\mathrm{c}}\end{array}$ & $\begin{array}{l}0.18 \\
0.18\end{array}$ & $\begin{array}{l}0.32^{\mathrm{a}} \\
0.31^{\mathrm{a}}\end{array}$ \\
\hline $\begin{array}{l}\text { OGTT } \\
\text { Glucose area } \\
\text { Insulin area }\end{array}$ & $\begin{array}{l}0.53^{\mathrm{b}} \\
0.47^{\mathrm{b}}\end{array}$ & $\begin{array}{l}0.55^{\mathrm{b}} \\
0.64^{\mathrm{b}}\end{array}$ & $\begin{array}{l}0.29 \\
0.13\end{array}$ & $\begin{array}{l}0.35^{\mathrm{a}} \\
0.26\end{array}$ \\
\hline
\end{tabular}

${ }^{\mathrm{a}} \mathrm{p}<0.05,{ }^{\mathrm{b}} \mathrm{p}<0.01,{ }^{\mathrm{c}} \mathrm{p}<0.001$

were characterized by a higher body fat content than men. However, despite the fact that women of the present study were fatter than the sample of men examined, they tended to show more favourable fasting plasma lipoprotein, insulin and glucose concentrations than men. This situation could perhaps be partly explained by the fact that women had more subcutaneous fat than men but showed no difference in visceral AT accumulation, this latter depot having been shown to be more closely related with alterations in the lipid profile as well as in the insulin-glucose homeostasis than excess fatness per se [36]. These results further emphasize the role of visceral fat as a correlate of the metabolic complications of obesity. In this regard, as a set of morphometric and metabolic variables was assessed in both men and women, the present study offered an opportunity to examine the potential associations of total body FM as well as of AT distribution indices to plasma leptin levels, and to test for potential gender differences in the magnitude of these relationships.

The obese gene product, leptin, is secreted and exclusively expressed by AT [2, 9-13]. Numerous 
studies have now reported strong positive correlations between total adiposity and fasting plasma leptin concentrations or its AT mRNA levels [14-21]. In the present study, an increased body FM was associated with higher plasma leptin concentrations in men and women. However, the slope of the relationship was steeper in women compared to men. This observation indicates that for a given total body FM, women show elevated plasma leptin concentrations compared to men.

In our study, the associations between plasma leptin and lipid concentrations were dependent of the degree of obesity as statistical adjustment for body FM did eliminate the associations. This is concordant with previous studies that reported no relationships between plasma leptin and lipid concentrations after statistical adjustment for adiposity [37, 38]. We also found highly significant correlations between plasma leptin concentrations and insulin levels measured in the fasting state or following an oral glucose challenge. However, this relationship was only independent of adiposity in women. These results are concordant with several previous studies where it was reported that insulin administration in vivo or insulin in vitro could increase AT obese gene mRNA levels $[3,13,22,23]$.

We also found a substantial difference in leptinaemia between men and women. Previous studies had suggested that this difference could be the result of the increased body fat content of women compared to men [14, 17, 20, 37-42]. However, this gender difference remained after adjustment of leptin for adiposity, mostly BMI $[14,17,20,37,38,40-42]$. In the present study, when women and men were matched for FM, a two-fold difference in leptinaemia remained, women having higher levels than men. It is also relevant to point out that women matched with men on the basis of body FM had lower plasma insulin levels than men. The understanding of the mechanism responsible for this phenomenon is beyond the scope of the present study and will require further investigation. However, gender differences in visceral AT could be suspected in men and women matched for total body fatness, lower values having been reported in women [43]. Indeed, in addition to higher plasma insulin concentrations, men also showed increased visceral AT accumulation compared to women. Thus, this elevated visceral AT depot, which is closely related to alterations in glucose-homeostasis [44], may contribute to the hyperinsulinaemic state in men.

Increased leptin production has been reported in subcutaneous vs intra-abdominal AT depots $[9,45]$. The well-known gender difference in AT distribution may account for some of the difference in leptin concentrations between men and women. However, in our study, men and women matched for FM displayed similar average levels of subcutaneous AT. Thus, it does not appear that increased subcutaneous AT in women is responsible for the difference in circulating leptin concentrations between men and women.

Recently, Rosenbaum et al. [39] have also reported a gender difference in leptin concentrations. They also observed a decrease in plasma leptin levels at menopause in women, but leptin concentrations in postmenopausal women remained higher than those found in men. In this regard, they proposed that oestrogen and/or progesterone could affect leptin levels resulting in elevated leptin concentrations in premenopausal women. Furthermore, they also proposed that the lower leptin levels that are reported in men, compared to women, could be due to elevated androgen concentrations. This hypothesis requires further investigation.

Another issue that will have to be examined is whether the proportion of free vs bound leptin in the plasma could be different between men and women. Indeed, Sinha et al. [46] have reported a difference in the proportion of free vs bound (i.e. associated to binding proteins) leptin between lean and obese subjects. In this study, it was also noted that obese subjects had higher leptin concentrations compared to lean individuals, and that a majority of the leptin in circulation was in the free form. Since free leptin is believed to be the bioactive form, these observations provide further support for the leptin resistance theory in human obesity. In the present study, women had increased adiposity and higher plasma leptin concentrations compared to men. However, matching subjects on the basis of FM did not eliminate the gender difference in leptin levels. In our study, we were not able to quantify the contributions of the two forms of leptin (free vs bound) to the total circulating concentration. However, in the event that a gender difference in the proportion of free vs bound leptin contributed to elevated plasma leptin levels in women, results of the present study suggest that this phenomenon is unlikely to be the result of increased adiposity.

In summary, the results of the present study clearly indicate that women have increased plasma leptin levels compared to FM-matched men. Since plasma leptin concentrations were not related to alterations of the plasma lipoprotein concentrations which are known risk factors for CVD, it does not seem relevant to include leptinaemia in the set of metabolic risk factors for CVD. Although this study was obviously not designed to examine the mechanisms that are involved in the regulation of the obese gene expression in AT, the present results reinforce the notion that, in women, leptin production in AT is related to insulinaemia, and that this relationship is independent of FM. However, further studies are needed to identify factors responsible for the marked difference in leptinaemia among men and women with similar levels of total body fat. 
A cknowledgements. The excellent collaboration of the staff of the Lipid Research Center, the Physical Activity Sciences Laboratory and the Diabetes Research Unit is gratefully acknowledged. Charles Couillard is a recipient of a Fonds pour la Formation de Chercheurs et l'Aide à la Recherche (FCAR) du Québec scholarship.

\section{References}

1. Kissebah AH, Krakower GR (1994) Regional adiposity and morbidity. Physiol Rev 74: 761-811

2. Zhang Y, Proenca R, Maffei M, Barone M, Leopold L, Friedman JM (1994) Positional cloning of the mouse obese gene and its human homologue. Nature 372: 425-432

3. Stephens TW, Basinski M, Bristow PK et al. (1995) The role of neuropeptide $\mathrm{Y}$ in the antiobesity action of the obese gene product. Nature 377: 530-532

4. Weigle DS, Bukowski TR, Foster DC et al. (1995) Recombinant $\mathrm{ob}$ protein reduces feeding and body weight in the ob/ob mouse. J Clin Invest 96: 2065-2070

5. Campfield LA, Smith FJ, Gulsez Y, DeVos R, Burn P (1995) Mouse ob protein: Evidence for a peripheral signal linking adiposity and central neural networks. Science 269: 546-549

6. Pelleymounter MA, Cullen MJ, Baker MB et al. (1995) Effects of the obese gene product on body weight regulation in ob/ob mice. Science 269: 540-543

7. Halaas JL, Gajiwala KS, Maffei M et al. (1995) Weight-reducing effects of the plasma protein encoded by the obese gene. Science 269: 543-546

8. Schwartz MW, Baskin DG, Bukowski TR et al. (1996) Specificity of leptin action on elevated blood glucose levels and hypothalamic neuropeptide $\mathrm{Y}$ gene expression in ob/ob mice. Diabetes 45: 531-535

9. Masuzaki H, Ogawa Y, Isse N et al. (1995) Human obese gene expression: Adipocyte-specific expression and regional differences in the adipose tissue. Diabetes 44: 855-858

10. Maffei M, Fei H, Lee GH et al. (1995) Increased expression in adipocytes of ob RNA in mice with lesions of the hypothalamus and with mutations at the db locus. Proc Natl Acad Sci USA 92: 6957-6960

11. Ogawa Y, Masuzaki H, Isse N et al. (1995) Molecular cloning of rat obese cDNA and augmented gene expression in genetically obese Zucker fatty ( $\mathrm{fa} / \mathrm{fa}$ ) rats. J Clin Invest 96 : 1647-1652

12. Murakami T, Shima K (1995) Cloning of rat obese cDNA and its expression in obese rats. Biochem Biophys Res Comm 209: 944-952

13. Leroy P, Dessolin S, Villageois P et al. (1996) Expression of ob gene in adipose cells: Regulation by insulin. J Biol Chem 271: 2365-2368

14. Maffei M, Halaas J, Ravussin E et al. (1995) Leptin levels in human and rodents: Measurement of plasma leptin and ob RNA in obese and weight-reduced subjets. Nature Med 1: 1155-1161

15. Hamilton BS, Paglia D, Kwan AYM, Deitel M (1995) Increased obese mRNA expression in omental fat cells from massively obese humans. Nature Med 1: 953-956

16. Lönnqvist F, Arner P, Nordfors L, Schalling M (1995) Overexpression of the obese (ob) gene in adipose tissue of human obese subjects. Nature Med 1: 950-953

17. Considine RV, Sinha MK, Heiman ML et al. (1996) Serum immunoreactive-leptin concentrations in normal weight and obese humans. New Engl J Med 334: 292-295

18. Considine RV, Considine EL, Williams CJ et al. (1995) Evidence against either a premature stop codon or the absence of obese gene mRNA in human obesity. J Clin Invest 95: 2986-2988

19. Vidal H, Auboeuf D, DeVos P et al. (1995) The expression of ob gene is not acutely regulated by insulin and fasting in human abdominal subcutaneous adipose tissue. J Clin Invest 98: 251-255

20. Dagogo-Jack S, Fanelli C, Paramore D, Brothers J, Landt M (1996) Plasma leptin and insulin relationships in obese and nonobese humans. Diabetes 45: 695-698

21. Klein S, Coppack SW, Mohamed-Ali V, Landt M (1996) Adipose tissue leptin production and plasma leptin kinetics in humans. Diabetes 45: 984-987

22. Saladin R, DeVos P, Guerro-Millo M et al. (1995) Transcient increase in obese gene expression after food intake or insulin administration. Nature 377: 527-529

23. MacDougald OA, Hwang CS, Fan H, Lane MD (1995) Regulated expression of the obese gene product (leptin) in white adipose tissue and 3T3-L1 adipocytes. Proc Natl Acad Sci USA 92: 9034-9037

24. The Airlie (VA) consensus conference (1988). In: Lohman T, Roche A, Martorel R (eds) Standardization of anthropometric measurements. Human Kinetics Publishers, Champaign, Illinois, pp 39-80

25. Behnke AR, Wilmore JH (1974) Evaluation and regulation of body build and composition. Prentice-Hall, Engelwood Cliffs, California

26. Siri WE (1956) The gross composition of the body. Adv Biol Med Phys 4: 239-280

27. Ferland M, Després JP, Tremblay A et al. (1986) Assessment of adipose tissue distribution by computed tomography in obese women: Association with body density and anthropometric measurements. Br J Nutr 61: 139-148

28. Després JP, Prud'homme D, Pouliot MC, Tremblay A, Bouchard C (1991) Estimation of deep abdominal adipose-tissue accumulation from simple anthropometric measurements in men. Am J Clin Nutr 54: 471-477

29. Kvist H, Tylen U, Sjöström L (1986) Adipose tissue volume determinations in women by computed tomography: Technical considerations. Int J Obesity 10: 53-67

30. Richterich R, Dauwalder H (1971) Zur bestimmung der plasmaglukosekonzentration mit der hexokinase-glucose6-phosphatase-dehydrogenase-methode. Schweiz Med Wochenschr 101: 615-618

31. Desbuquois B, Aurbach GD (1971) Use of polyethylene glycol to separate free and antibody-bound peptide hormones in radioimmunoassay. J Clin Endocrinol Metab 37: $732-738$

32. Moorjani S, Dupont A, Labrie F et al. (1987) Increase in plasma high-density lipoprotein concentration following complete androgen blockage in men with prostatic carcinoma. Metabolism 36: 244-250

33. Burstein M, Samaille J (1960) Sur un dosage rapide du cholestérol lié aux $\beta$-lipoprotéines du sérum. Clin Chim Acta 5: 609-610

34. Gidez LI, Miller GJ, Burstein M, Slage S, Eder HH (1982) Separation and quantitation of subclasses of human plasma high density lipoproteins by a simple precipitation procedure. J Lip Res 23: 1206-1223

35. Avogaro P, Bittolo Bon G, Cazzolato G, Quinci GB (1979) Are apolipoprotein better discriminators than lipids for atherosclerosis? Lancet 1: 901-903

36. Després JP (1991) Obesity and lipid metabolism: Relevance of body fat distribution. Curr Opin Lipdol 2: 5-15

37. Ostlund RE, Yang JW, Klein S, Gingerich R (1996) Relation between plasma leptin concentration and body fat, gender, diet, age and metabolic covariates. J Clin Endocrinol Metab 81: 3909-3913 
38. Hickey MS, Israel RG, Gardiner SN et al. (1996) Gender differences in serum leptin levels in humans. Biochem Molec Med 59: 1-6

39. Rosenbaum M, Nicolson M, Hirsch J et al. (1996) Effects of gender, body composition and menopause on plasma concentrations of leptin. J Clin Endocrinol Metab 81: 3424 3427

40. Ma Z, Gingerich RL, Santiago JV, Klein S, Smith CH, Landt M (1996) Radioimmunoassay of leptin in human plasma. Clin Chem 42: 942-946

41. Schwartz MW, Peskind E, Raskind M, Boyko EJ, Porte D (1996) Cerebrospinal fluid leptin levels: Relationship to plasma levels and to adiposity in humans. Nature Med 2: 589-593

42. Haffner SM, Gingerich RL, Miettinen H, Stern MP (1996) Leptin concentrations in relation to overall adiposity and regional body fat distribution in Mexican Americans. Int $\mathbf{J}$ Obes 20: 904-908
43. Lemieux S, Prud'homme D, Bouchard C, Tremblay A, Després JP (1993) Sex differences in the relation of visceral adipose tissue accumulation to total body fatness. Am J Clin Nutr 58: 463-467

44. Lemieux S, Després JP (1994) Metabolic complications of visceral obesity: contribution to the etiology of type 2 diabetes and implications for prevention and treatment. Diabete Metab 20: 375-393

45. Hube F, Lietz U, Igel M et al. (1996) Difference in leptin mRNA levels between omental and subcutaneous abdominal adipose tissue from obese humans. Horm Metab Res 28: 690-693

46. Sinha MK, Opentanova I, Ohanessian JP et al. (1996) Evidence of free and bound leptin in human circulation - studies in lean and obese subjects and during short-term fasting. J Clin Invest 98: 1277-1282 